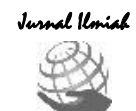

MUQODDIMAH

\title{
STUDI DESKRIPTIF MENGENAI OPINI MAHASISWA TERHADAP FENOMENA APLIKASI WHATSAPP DI UNIVERSITAS MUHAMMADIYAH TAPANULI SELATAN
}

\author{
Sigit Hardiyanto, S.Sos, M.I.Kom ${ }^{1}$ \\ Ali Sahbana, S.Sos, M.Si ${ }^{2}$ \\ Universitas Muhammadiyah Tapanuli Selatan \\ Sigit.hardiyanto@um-tapsel.ac.id ${ }^{1}$ \\ Ali.sahbana@um-tapsel.ac.id ${ }^{2}$
}

\begin{abstract}
Abstrak
Penelitian ini bertujuan untuk mengetahui bagaimana opini mahasiswa terhadap fenomena aplikasi whatsapp di Universitas Muhammadiyah Tapanuli Selatan Jenis penelitian yang digunakan adalah penelitian kualitatif dengan pendekatan studi fenomenologi. Teknik pengumpulan data melalui observasi, wawancara dan dokumentasi. Hasil penelitian menunjukkan karakter fisik pesan saat menggunakan aplikasi whatsapp sangat mempengaruhi makna yang ditimbulkan pada proses pengiriman pesan baik dalam bentuk pesan suara maupun tulisan. Kualitas warna dapat memiliki daya tarik bagi pengguna aplikasi whatsaap ketika menggunakan aplikasi whatsaap. Warna yang menarik dapat memberikan dan membantu artikulasi dari pesan yang disampaikan melalui aplikasi whatsaap. Aplikasi whatsaap sangat menguntungkan bagi manusia dalam menyebarluaskan informasi. Selain menyebarkan informasi juga digunakan untuk sharing antar pengguna mengenai hal yang difikirkan dan dirasakan masing-masing individu.
\end{abstract}

Kata Kunci : Opini Publik, Komunikasi, Aplikasi Whatsapp

\begin{abstract}
His study aims to find out how student opinions on the phenomenon of whatsapp application at Muhammadiyah University of South Tapanuli. The type of research used is qualitative research with a phenomenological study approach. The technique of collecting data through observation, interviews and documentation. The results of the study show that the physical character of the message when using the WhatsApp application greatly influences the meaning generated in the process of sending messages both in the form of voice messages and writing. Color quality can have an appeal for whatsaap application users when using the whatsaap application. Attractive colors can provide and help the articulation of messages delivered through the application whatsaap. The application of whatsaap is very beneficial for humans in disseminating information. In addition to disseminating information, it is also used for sharing between users about what each individual thinks and feels.
\end{abstract}

Keywords: Public Opinion, Communication, Whatsaap Application

Volume 3, Nomor 2, Agustus 2019 
PENDAHULUAN

\begin{tabular}{lr}
\multicolumn{2}{c}{ Komunikasi merupakan } \\
kebutuhan yang & sangat \\
mendasar dalam & kehidupan \\
manusia dan & mempunya
\end{tabular} peranan yang sangat penting pada masa sekarang ini. Sejalan dengan itu, kemajuan teknologi lainnya yang turut membawa kemajuan besar, khususnya bagi perkembangan teknologi komunikasi, perkembangan teknologi komunikasi ditandai dengan perubahan besar pada media komunikasi, baik media cetak maupun elektronik.

Dalam era modern seperti saat sekarang ini, kehidupan masyarakat tidak terlepas dari pengaruh hadirnya teknologi baru. Teknologi merupakan kepentingan yang amat berarti dalam kehidupan masyarakat. Pemanfaatan media komunikasi khususnya whatsapp sudah menjadi fenomena yang terjadi di kalangan mahasiswa khususnya mahasiswa Fakultas IImu Sosial dan IImu Politik Universitas Muhammadiyah Tapanuli Selatan seiring perkembangan teknologi komunikasi yang semakin canggih. Media komunikasi dalam jaringan menjadi bentuk media baru sejak kemunculan whatsapp dan berpotensi mengubah pola komunikasi dalam interaksi mahasiswa. Interaksi termediasi media baru secara otomatis tidak mengharuskan pertemuan secara fisik untuk menyebarkan sebuah informasi atau sekadar berbagi pengalaman.

Pemanfaatan media komunikasi khususnya whatsapp sudah menjadi fenomena yang terjadi di kalangan mahasiswa khususnya mahasiswa Fakultas IImu Sosial dan IImu Politik Universitas Muhammadiyah Tapanuli Selatan seiring perkembangan teknologi komunikasi yang semakin canggih. Media komunikasi dalam jaringan menjadi bentuk media baru sejak kemunculan whatsapp dan berpotensi mengubah pola komunikasi dalam interaksi mahasiswa. Interaksi termediasi media baru secara otomatis tidak mengharuskan pertemuan secara fisik untuk menyebarkan sebuah informasi atau sekadar berbagi pengalaman.

\section{Rumusan Masalah}

Peneliti merumuskan masalah dari penelitian ini adalah bagaimana opini mahasiswa terhadap fenomena aplikasi whatsapp di Universitas Muhammadiyah Tapanuli Selatan?

\section{Tujuan dan Manfaat Penelitian}

Tujuan penelitian ini adalah untuk mendapatkan gambaran bagaimana opini mahasiswa terhadap fenomena aplikasi whatsapp di Universitas Muhammadiyah Tapanuli Selatan. Sedangkan manfaat 
penelitian adalah diharapkan dapat memperkaya khasanah penelitian di FISIP Universitas Muhammadiyah Tapanuli Selatan serta sebagai penerapan ilmu sosial dan juga memberikan masukan bagi peneliti lain jika akan mengadakan penelitian yang sama.

\section{TINJAUAN PUSTAKA}

\section{Opini Publik}

Opini menurut

Olii (2007:20) adalah pendapat, ide ataupun hasil pikiran manusia untuk menjelaskan kecenderungan atau preferensi tertentu terhadap perspektif dan ideologi akan tetapi bersifat tidak objektif karena belum mendapatkan pemastian atau pengujian, dapat pula merupakan sebuah pernyataan tentang sesuatu yang berlaku pada masa depan dan kebenaran atau kesalahannya serta tidak dapat langsung ditentukan misalnya menurut pembuktian melalui induksi.

Publik (dalam Hegar, 2011:11) adalah umum, seperti yang diketahui bahwa kata publik tersebut pada dasarnya biasa digunakan untuk hal yang bersifat umum, ataupun dinikmati oleh orang bnyak dan juga bisa dikatakan bahwa publik tersebut adalah menyangkut hal-hal yang bersifat universal atau menyeluruh. Salah satu strategi komunikasi didesain untuk membangun reputasi institusi. Salah satu pendekatan yang dipakai adalah penciptaan opini publik yang positif. Opini publik mempunyai beberapa arti antara lain (dalam Afdhal, 2005:29) sebagai keinginan kolektif dari masyarakat. Arti lain dari terminologi ini adalah sikap yang dominan dari masyarakat. Selain itu, opini publik bisa dilihat sebagai ekspresi masyarakat tentang isu yang spesifik.

\section{Komunikasi}

Berger dan Chaffe (dalam Wiryanto, 2004: 3) menerangkan ilmu komunikasi adalah "Communication science seeks to understand the production, processing and effect of symbol and signal system by developing testable theories containg lawfull generalization, that explain phenomena associated with production, processing and effect". (IImu komunikasi itu mencari untuk memahami mengenai produksi, pemrosesan dan efek dari simbol serta sistem signal dengan mengembangkan pengujian teori-teori menurut hukum generalisasi guna menjelaskan fenomena yang berhubungan dengan produksi, pemrosesan dan efeknya).

Komunikasi mengandung makna bersama-sama (common). Istilah komunikasi atau communication berasal dari bahasa Latin, yaitu communicatio 
yang berarti pemberitahuan atau pertukaran. Kata sifatnya communis yang bermakna umum atau bersama-sama.

Teknologi komunikasi bisa berkembang dengan cepat karena bantuan teknologi elektronika. Dengan teknologi elektronika, proses komunikasi tidak lagi dibatas oleh ruang dan waktu. Teknologi elektronika ini kemudian membentuk prinsip dasar teknologi komunikasi yakni (Ishadi dalam Abrar, 2003:5) :

1. Objek bisa dirubah menjadi menjadi gambar melalui pendekatan lensa

2. Gambar proyeksi bisa dirubah menjadi gelombang

elektromagnetik melalui pendekatan fotosel (scanning device)

3. Suara bisa diubah menjadi sinyal listrik melalui pendekatan microphone

4. Sinyal listrik yang bermuatan gambar proyeksi dan suara dipancarkan melalui kabel. Melalui jasa satelit komunikasi, sinyal listrik bisa saja dikirim kemana saja di muka bumi bahkan ke ruang angkasa sekalipun

5. Sinyal diterima sistem antena dan masuk ke alat yang bisa mengubah sinyal menjadi gambar proyeksi kembali. Gambar ini bisa dilihat di layar monitor, digandakan dan dicetak.

Pemanfaatan teknologi komunikasi dewasa ini ditandai pengguna ponsel yang berbasis android. Hal ini banyak ditemukan penggunaan smartphone di masyarakat khususnya mahasiswa. penggunaan smartphone digunakan sebagai media komunikasi salah satunya chatting. Chatting berasal dari synchronous chats (ngobrol bareng) melalui internet. Chatting diawali dengan keinginan untuk memuaskan kerinduan psikologis individu yang alamiah, seperti kontak sosial, hiburan dan informasi baru. Ini merupakan kebutuhan dasar manusia. Karena itu, setiap individu berusaha untuk memuaskannya. Dalam proses pemuasan ini, bisa saja chatting berkembang menjadi ajang pencarian pekerjaan, cari pacar dan cari jodoh. Mayanya tergantung pada individu yang melakukan chatting yang biasa disebut chatter.

Lewat chatting, seorang chatter bisa mengembarakan pikirannya kemana-mana. Dia juga bisa menyampaikan informasi tentang dirinya semaunya. Kenyataan semacam ini melahirkan anggapan bahwa chatting merupakan sarana untuk memanipulasi identitas dan memperoleh harapan baru. Yang terakhir ini sangat dibutuhkan oleh para remaja, terutama 
mereka yang mengalami kecemasan hebat (angst) menghadapi masa depan.

Teoriinteraksi simbolik dipengaruhi oleh struktur sosial yang membentuk atau menyebabkan perilaku tertentu yang kemudian membentuk simbolisasi dalam interaksi sosial masyarakat. Teori interaksi simbolik menuntut setiap individu harus proaktif, reflektif, dan kreatif, menafsirkan, menampilkan perilaku yang unik, rumit dan sulit untuk diinterpretasikan. Teori ini menekankan dua hal yakni manusia dalam masyarakat tidak pernah lepas dari interaksi sosial dan interaksi dalam masyarakat terwujud dalam simbol-simbol tertentu yang cenderung sifatnya dinamis.

Pada dasarnya teori interaksi simbolik berakar dan berfokus pada hakikat manusia sebagai makhluk relasional. Setiap individu pasti terlibat relasi dengan sesamanya. Tidaklah mengherankan bila dibandingkan dengan teori-teori sosial lainnya. Alasannya adalah diri manusia muncul dalam dan melalui interaksi dengan yang diluar dirinya. Interaksi itu sendiri membutuhkan simbol-simbol tertentu. Simbol itu biasanya disepakati bersama dalam skala kecil maupun dalam skala besar.

Penerimaan informasi sama kompleks dan pentingnya dengan pengiriman pesan.
Penerimaan informasi melibatkan dan mengubah pesan kedalam suatu bentuk yang dapat digunakan untuk memandu perilaku. Adapun indikator pengaruh penerima antara lain Pertama kebutuhan. Diantara faktor yang paling penting dan berperan dalam penerimaan pesan adalah apa yang disebut denga kebutuhan. Kebutuhan atau motif lain setelah kebutuhan dasar meliputi kontak sosial, eksplorasi dan komprehensi realitas, sosislitas, diversi, hiburan dan permainan, semua itu berkaitan dengan kondisi kesejahteraan jiwa, psikologis, sosial dan komunikasi kita. (Brent, 2013:114). Kedua penggunaan. Kita tertarik memerhatikan pesan, belajar menafsirkan dan mempertahankannya dengan bagaimana kita dapat menggunakan bahasa lisan, karena semua itu penting untuk keikutsertaan kita dalam hampir seluruh aktivitas manusia.

Pengaruh

pesan

(informasi) tentu sebagian besar penting bagi kita, muncul secara langsung atau tidak langsung dari kegiatan orang lain melalui komunikasi. Adapun indikator pengaruh pesan antara lain Pertama karakteristik fisik. Pesan memiliki kecerahan, memiliki warna hidup atau intensitas lebih cenderung untuk diperhatikan dan diperhitungkan dibandingkan yang tidak. Kedua kebaruan. 
Informasi yang baru, asing atau muncul diluar kebiasaan merebut perhatian kita untuk sesaat.

\section{Sejarah Whatsapp}

Pembuat aplikasi Whatsapp adalah dua orang mantan karyawan Yahoo Inc. yang memiliki pengalaman teknis selama 20 tahun, yaitu Brian Acton dan Jan Koum. Mereka memberi nama Whatsapp dari asal kata What's up yang berarti Apa kabar. Aplikasi Whatsapp diciptakan dengan tujuan agar terdapat alternatif lain yang lebih bagus dari SMS.

Whatsapp merupakan aplikasi berkirim pesan (messenger / chatting) yang populer digunakan oleh pengguna smartphone yang memiliki operasi sistem Android. Selain Android, Whatsapp juga disediakan

di iOS (iPhone), Windows Phone, BlackBerry dan Nokia. Whatsapp tidak hanya digunakan untuk berkirim pesan saja, tetapi Whatsapp juga bisa digunakan untuk menelpon serta berkirim gambar/ foto, video dan audio tanpa ada batas ukuran. Selain itu pihak Whatsapp juga menyediakan fitur grup yang memungkinkan kita untuk melakukan diskusi dengan kelompok yang berisikan orangorang pilihan pemilik grup. Bahasa yang disediakan sangat bervariasi seperti Bahasa Indonesia, Melayu, Inggris,
Jerman, Perancis, Italia, Belanda, Spanyol, Portugis, Rumania, Vietnam, Turki, dan bahasabahasa lainnya.

Whatsapp messenger

(dalam Nurhakim, 2015:104) adalah aplikasi pesan lintas platform yang memungkinkan kita bertukar pesan tanpa membayar untuk SMS. Whatsapp messenger menggunakan internet seperti juga untuk email browsing web dan lain-lain sehingga tidak menggunakan biaya untuk dapat tetap berhubungan.

Awalnya, whatsapp dibuat pengguna iPhone, kemudian seiring perkembangannya, aplikasi whatsaap tersedia juga untuk versi Blackberry, Android dan Symbian. Whatsaap memiliki fitur untuk mengirim gambar, video, suara dan lokasi GPS via hardware GPS atau Gmaps. Media tersebut langsung dapat ditampilkan dan buka berupa link. Whatsapp, layaknya SMS tidak perlu membuka aplikasi untuk menerima sebuah pesan. Notifikasi pesan masuk ketika handphone sedang off akan tetap disampaikan jika handphone sudah on. Saat ini, Whatsapp telah menjelma jadi layanan pesan instan terbesar dengan jumlah pengguna aktif per bulan mencapai 450 juta. Setiap hari, sebanyak 18 miliar pesan dikirim melalui jaringannya. Semua itu ditangani dengan jumlah karyawan hanya 50 orang. 
Metode Penelitian

Penelitian Ini Termasuk Jenis Penelitian Kualitatif Dengan Fokus Kajian Terutama Mengenai Bagaimana Opini Mahasiswa Terhadap Fenomena Aplikasi Whatsapp Di Universitas Muhammadiyah Tapanuli Selatan

\section{Teknik Pengumpulan Data}

Untuk kelancaran dalam penelitian ini, maka penulis sangat memerlukan data-data yang relevan yang diperoleh melalui teknik-teknik berikut ini, yaitu:

1. Penelitian Kepustakaan (Library Research)

Kepustakaan adalah kumpulan sumber bacaan terpilih atau dengan judul penelitian untuk memperkuat atau sebagai argumentasi pendukung terhadap pemikiran yang dinginkan penelitian. Tujuan penelitian kepustakaan ini adalah untuk mengumpulkan data dan informasi dengan bantuan bermacam-macam material yang terdapat di ruang kepustakaan, misalnya buku-buku, majalahmajalah, naskah-naskah, kiasankiasan sejarah dan lain-lain.

\section{Penelitian Lapangan} (Field Research)

Merupakan kegiatan

penelitian untuk mencari data dan informan yang lengkap dan akurat yang dilakukan secara langsung ke lokasi penelitian melalui rangkaian berikut:

a. Wawancara.

Teknik pengumpulan data dilakukan dengan wawancara. Tujuan utama melakukan wawancara adalah untuk bisa menyajikan konstruksi saat sekarang dalam suatu konteks mengenai para pribadi, peristiwa, aktivitas, organisasi, perasaan, motivasi, tanggapan atau persepsi, tingkat dan bentuk keterlibatan dan sebagainya, untuk merekonstruksikan beragam hal seperti itu sebagai bagian dari pengalaman masa lampau, dan memproyeksikan hal-hal yang dikaitkan dengan harapan yang bisa terjadi di masa yang akan datang (Sutopo, 2006: 68). Wawancara

percakapan informal (the informal conversational interview) menunjuk pada kecenderungan sifat sangat terbuka dan sangat longgar (tidak terstruktur) sehingga wawancara memang benarbenar mirip dengan percakapan. Pertanyaan yang subjek lain, subjek yang sama kadang kala harus didatangi oleh peneliti untuk pertanyaan yang berbeda atau mirip sehingga jawaban terdahulu mungkin 
dapat ditambahkan atau direvisi oleh subjek (Pawito, 2007:132). Wawancara dilakukan di kampus Universitas Muhammadiyah Tapanuli Selatan.

b. Observasi. Menurut Idrus (2009:101), observasi atau pengamatan merupakan aktivitas pencatatan fenomena yang dilakukan secara sistematis. Pengamatan dapat dilakukan secara terlibat (partisipasif) ataupun nonpartisipasif. Maksudnya, pengamatan terlibat merupakan jenis pengamatan yang melibatkan peneliti dalam kegiatan orang yang menjadi sasaran penelitian, tanpa mengakibatkan perubahan pada kegiatan atau aktivitas yang bersangkutan. Untuk menyempurnakan aktivitas pengamatan partisipasif ini, peneliti harus mengikuti kegiatan keseharian yang dilakukan oleh informan dalam waktu tertentu, memerhatikan apa yang terjadi, mendengarkan apa yang dikatakannya, mempertanyakan informasi yang menarik, dan mempelajari dokumen yang dimiliki.

c. Dokumentasi, yaitu melalui pengambilan data dari dokumen-dokumen, pedoman-pedoman, peraturan-peraturan, undang-undang yang mendukung penelitian.

\section{Tempat Penelitian}

Penelitian ini berlangsung di lingkungan kampus Universitas Muhammadiyah Tapanuli Selatan yang beralamat Jalan Sutan. Mohd Arief Nomor 32 Padangsidimpuan.

Hasil Penelitian dan Pembahasan

Penemuan terbaru mengatakan bahwa bumi dihuni oleh makhluk hidup sejak empat miliar tahun yang lalu yang lalu. Manusia memperoleh kemampuan fisik untuk berbicara, manusia memiliki jiwa dan raga yang dilengkapi dengan panca indera (mata, telinga, hidung, kulit, lidah) yang berfungsi menerima stimulus dari luar, kemudian diserap kedalam jaringan syaraf dalam bentuk getaran-getaran ke otak atau pusat syaraf. Media memberikan pengaruh terhadap opini public, Noelle-Neumann menjelaskan bahwa media tidak memberikan interpretasi yang luas dan seimbang terhadap peristiwa sehingga masyarakat memiliki pandangan terhadap realitas secara terbatas dan sempit.

Pentingnya pemberian informasi bagi pengguna media sosial sangat membantu pengguna dalam menggunakan 
media sosial dengan efektif dan efisien. Informasi yang diberikan bertujuan untuk memberikan informasi terbaru mengenai produk.

Masyarakat informasi online dapat dijelaskan bagaimana masyarakat dalam hubungan dengan aktifitas informasi dan komunikasi yang difasilitasi oleh kemampuan produk Information and Communication Technologies (ICT) modern berupa aplikasi whatsapp. Dalam hal ini, masyarakat informasi sendiri digambarkan bahwa masyarakat khususnya mahasiswa memiliki kemampuan dalam menggunakan aplikasi berbasis online yaitu menciptakan, mendistribusikan, menggunakan dan memanfaatkan informasi untuk kepentingan seseorang dalam memenuhi kebutuhan informasi dalam hidupnya.

Keberadaan aplikasi

whatsaap sangat menguntungkan bagi manusia dalam menyebarluaskan informasi. Selain menyebarkan informasi juga digunakan untuk sharing antar pengguna mengenai hal yang difikirkan dan dirasakan masing-masing individu seperti contoh di kalangan mahasiswa dalam menggunakan aplikasi whatsapp biasanya mengenai kegiatan yang berkaitan dengan akademik seperti informasi tugas yang diberikan dosen, kehadiran dosen, sharing dengan sharing dengan sesama mahasiswa. Selain itu informasi tugas yang diberikan dosen, pesan juga dapat dikirimkan melalui gambar yang memiliki makna dalam memberikan pesan dan motif mahasiswa dalam menggunakan aplikasi whatsaap selain lebih irit juga akses lebih cepat dan memiliki fitur video call yang dapat digunakan kapan saja dan dimana saja.

Kualitas warna dapat memiliki daya tarik visual bagi pengguna aplikasi whatsaap ketika menggunakan aplikasi whatsaap. Warna yang menarik dapat memberikan dan membantu artikulasi dari pesan yang disampaikan melalui aplikasi whatsaap. Menggunakan aplikasi whatsaap dapat meningkatkan kebersamaan bagi penggunanya seperti video call, chat, group chat. Karakter fisik pesan saat menggunakan aplikasi whatsapp sangat mempengaruhi makna yang ditimbulkan pada proses pengiriman pesan baik dalam bentuk pesan suara maupun tulisan

\section{Kesimpulan dan Saran Kesimpulan}

1. Karakter fisik pesan saat menggunakan aplikasi whatsapp sangat mempengaruhi makna yang ditimbulkan pada proses pengiriman pesan baik dalam 
bentuk pesan suara maupun tulisan

2. Kualitas warna dapat memiliki daya tarik bagi pengguna aplikasi whatsaap ketika menggunakan aplikasi whatsaap. Warna yang menarik dapat memberikan dan membantu artikulasi dari pesan yang disampaikan melalui aplikasi whatsaap

3. Keberadaan aplikasi whatsaap menguntungkan sangat bagi manusia dalam menyebarluaskan informasi. Selain menyebarkan informasi juga digunakan untuk sharing antar pengguna mengenai hal yang difikirkan dan dirasakan masing-masing individu.

4. Keberadaan aplikasi whatsaap memberikan keuntungan bagi mahasiswa seperti tukar informasi, sharing dan dapat meningkatkan kebersamaan bagi pengguna

\section{Saran}

1. Diharapkan mahasiswa tetap bijak dalam menggunakan aplikasi whatsaap agar tidak terjadinya perilaku yang bertentangan dengan norma yang berlaku dimasyarakat

2. Mahasiswa harus mampu menyaring pesan yang diberikan oleh rekan sesama mahasiswa pada saat menggunakan aplikasi whatsaap

3. Mahasiswa tetap harus bijak dalam menggunakan teknologi informasi komunikasi yang menyangkut jejaring sosial dikarenakan jejaring sosial dapat membahayakan mahasiswa apabila tidak digunakan secara bijak.

\section{Daftar Pustaka}

Abrar, Ana. 2003. Teknologi Komunikasi Perspektif IImu Komunikasi. Yogyakarta: LESFI

Alyusi, Shiefti. 2016. Modal Sosial Interaksi, Identitas dan Modal Sosial. Jakarta:Kencana

Anne $\quad 2001$. Perencanaan dan Manajemen Kampanye Public Relation. Jakarta:Erlangga

Arif, Syaiful. 2000.Menolak Pembangunanisme.Yogya karta:Pustaka Pelajar

Effendy, Onong. 2003. IImu, Teori dan Filsafat Komunikasi. Bandung: Citra Aditya Bakti

Idrus, Muhammad. 2009. Metode Penelitian IImu Sosial: Pendekatan Kualitatif dan Kuantitatif. Jakarta: Erlangga

Moleong, Lexy J. 2009. Metode Penelitian Kualitatif. Bandung: Remaja Rosdakarya 
Morissan. $2013 . \quad T e o r i$

Komunikasi Individu Hingga

Massa. Jakarta: Kencana

Prenada Media Group

Mulyana, Dedi. 2010. IImu

Komunikasi Suatu

Pengantar. Bandung:

Remaja Rosdakarya

Nurhakim, Syarif. 2015. Dunia Komunikasi dan Gadget: Evolusi Alat Komunikasi, Menjelajah Jarak dengan Gadget. Jakarta: Bestari Buana Murni

Olii, Helena. 2007. Opini Publik. Jakarta: PT Indeks

Ruben, Brent. 2013. Komunikasi dan Perilaku Manusia. Jakarta:Rajawali Pers

Rumanti, Maria. 2002. Dasardasar Public Relation. Jakarta: Grasindo

Sutopo,H.B.2006. Metodologi Penelitian Kualitatif:Dasar Teori dan Terapannya Dalam Penelitian. Edisi2.Surakarta: Universitas Sebelah Maret. 